\title{
Applying the Gamification in Knowledge Management System
}

\author{
Vian Endramanto ${ }^{1}$, Rapsodi Anugrah Telaumbanua ${ }^{2}$, Inggrid Suparman ${ }^{3}$, Gunawan Wang ${ }^{4}$, Emil Robert Kaburuan ${ }^{5}$ \\ ${ }^{1}$ PT PLN (Persero) Pusdiklat UPDL Jakarta, Indonesia, 11440. \\ 2,3,4,5 Information Systems Management Department, BINUS Graduate Program - Master of Information Systems Management, \\ Bina Nusantara University, Indonesia, 11480. \\ 11vian.endramanto@pln.co.id, ${ }^{2}$ rapsodi.telaumbanua@binus.ac.id, ${ }^{3}$ inggrid.suparman@binus.ac.id, ${ }^{4}$ gwang@binus.edu, \\ 5 emil.kaburuan@binus.edu
}

Received Date : August 05, 2021 Accepted Date : September 17, 2021 Published Date : October 06, 2021

\begin{abstract}
This article explains the usage and benefit of incorporating gamification into the company's management system. The reason this paper is made because many not engaged and actively disengage employee exist, and the problem also occur in PT. XYZ where they still have no knowledge management system. We understand from the research done that by having just knowledge management is not enough since it will not automatically improve employee's engagement rate, therefore by implementing gamification and incorporating it with the knowledge management system could be the solution to increase company's engagement rate. The design of the business process design of this system is made using Activity Diagrams and Use Case Diagrams. While the database design is explained in the form of Entity Relationship Diagrams $(E R D)$. There might be many challenges and problems appeared within the company to make the system run smoothly from the technical and culture side of the company.
\end{abstract}

Key words: Gamification, Knowledge, Knowledge Management System

\section{INTRODUCTION}

"What kind of games do you play?" are word that we often hear we are still just a child, even in adulthood the word still sticks to us as if it is a natural habit that people do in their daily life. Playing games is one of the things that people do to release stress after a long day at work, since playing games increase your self-confidence and improves your mood[1]. Since playing games brings a lot of positive impact to people, does it have to stop there? Can we use it in other aspects of live? These are some of the questions we will discuss through this paper.

One of the aspects that will be mention, is the use of Gamification in company as way to improve their human resource, because human resource is one of the aspects that is needed for the sake of a good business. Gamification is the use of game-design elements in a particular task, providing more intense interaction on the exchange of information and encouraging the involvement of the public in a playful way[2]. According to Jonathan long, "your team is the company's backbone and one cancerous person can completely derail your progress."[3].First, looking back to the history, Gamification has existed since 1973 when the power of games is recognized as a way to engage employees[4]. Employee engagement is divided into three categories, which are: engaged, not engaged, and actively disengaged. An engaged employee is a builder, they will show their skill and willingness to work, on the other handnot engaged employee only focus on their task instead of the company's objective, after that an actively disengaged employee is full of negativity and spread that negativity to the engaged employee [5]. Therefor it is better to minimize, and further decrease the number of or even mutate the actively disengaged employees into an engaged employee. 85\% of employees in the world is not happy with their job and only $15 \%$ of average working adult feel engaged. By fixing the employee engagement problem help company to increase profit, promote business development, lower turnover rate, and improve company's efficiency rate [6].

There are many reasons why employee's engagement is low, such as lack of employee recognition, lack of transparency, and disconnection from peers [7], but there are also many ways to increase it and one of the way is through gamification, as mentioned in previous paragraph. Gamification is defined as the use of "game-based mechanics, aesthetics, and game thinking to engage people, motivate action, promote learning, and solve problems."[8]. Though the use of gamification is also widely used in many parts of the company, in this paper we will discuss of how it can be used to improve human resource of a company by implementing gamification in a company's knowledge management.

Why knowledge management? As we are using the case study happen in PT. XYZ, we discover that PT. XYZ is lacking in their knowledge management aspect, those problems are: the flow of communication which does not transferred smoothly, lacking in access for information, and there is no efficiency in the company's business process. As we discover that 
implementing knowledge management system is not enough, we figure by incorporating knowledge management system with gamification will help to engage, especially the sales (promotor) lack of engagement and knowledge sharing, which is one of the reasons of their poor selling. According to knowledge management tools.com, "knowledge management implies a strong tie to organizational goals and strategy, and it involves the management of knowledge that is useful for some purpose and which creates value for the organization."[9]. Using gaming mechanism and design technique in a gamified environment can encourage learning through entertainment since it awakens and increases interest and enhances pleasure while performing a task [2]. As shown in Figure 1, the position we aim to improve by implementing knowledge management system in corporate with gamification is the promotor. Further data and process will be explained in the next sections, which are divided into literature review, research method, proposed model, and discussion.

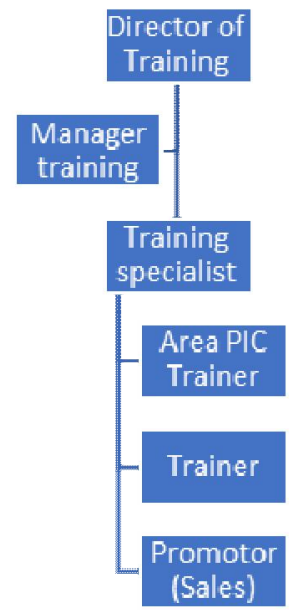

Figure 2: Corporate Structure for Sales Division

\section{LITERATUR REVIEW}

\subsection{Gamification for Knowledge Management}

Knowledge management is a concept that has existed since 1990's. One of the main purpose of knowledge management is to use practical and company's technology than use it to utilize company's knowledge [10]. According to Stan Garfield, "knowledge management enables an organization to better: share what has been learned, created, and proved to allow others to learn from the experience of the organization and reuse what has already been done, Innovate by being more creative, inventive, and imaginative, resulting in breakthroughs from bold new ways of thinking and doing, Reuse what others have already learned, created, and proved to save time and money, minimize risk, and be more effective, Collaborate with others to yield better results, benefit from diverse perspectives, and tap the experience and expertise of many other people, Learn by doing, from others, and from existing information to perform better, solve and avoid problems, and make good decisions." [11]. Knowledge management is accessible and usable in many areas of the company, as seen in figure 2 is a diagram of the usage of knowledge management in crucial part of the company also are the area where gamification can, already does and will be influencing knowledge management [12]. The topic we discuss in this paper includes in the area of Human Resource Management since we will discuss on how to incorporate gamification with knowledge management system to improve human resource.

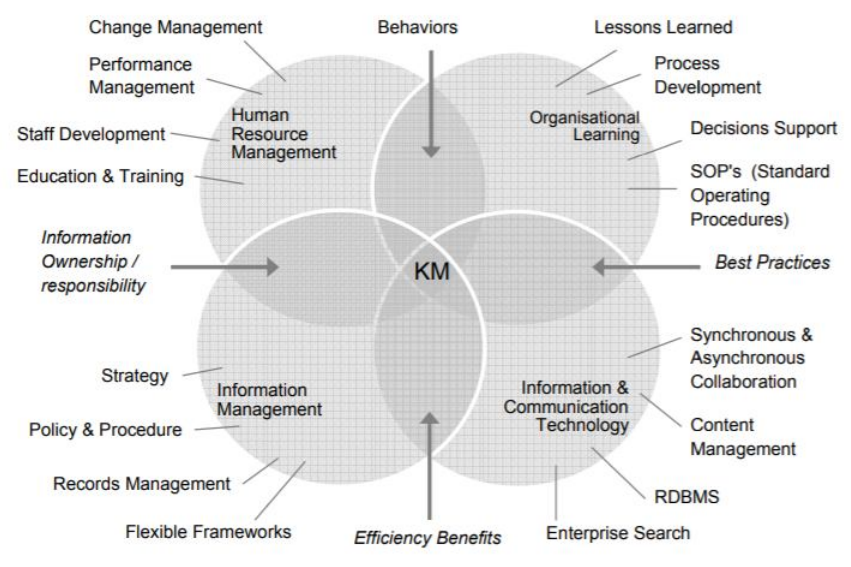

Figure 1: Knowledge Management strategies, methods and tools

Gamification, as already discussed before, is the implementation of games design elements with the purpose to increase motivation of the party addressed[13]. There are three aspects of gamification, which are: game dynamics, mechanics, and components. The most direct and concrete forms of gamification are game components such as points, rankings, levels or quests that area implemented in a system. These components show the mechanics of the game which have the same value as incentives, in other words: challenge, competition, feedback, rewards or cooperation and creating various motivational dynamics.

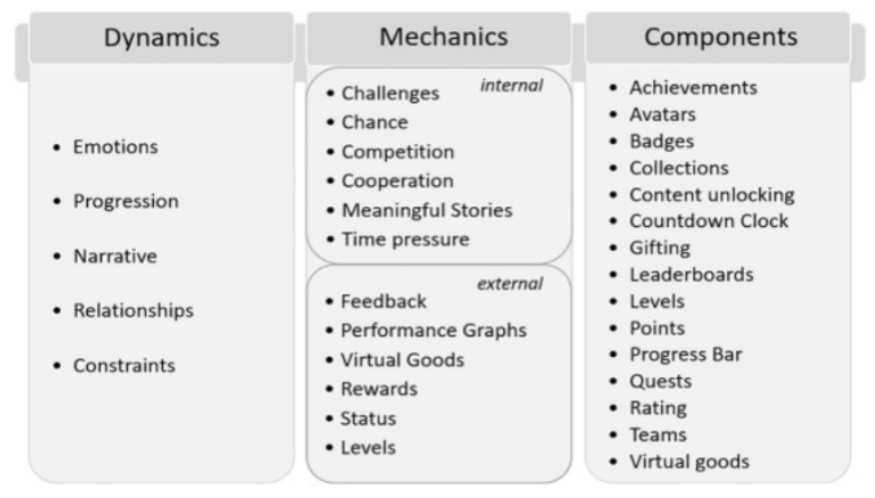

Figure 3 :Aspects of Gamification 
Dynamics cannot be implemented or managed directly [14] but unquestionably have impact on motivation. The overview of gamification concept can be seen in figure 3. According to Julia Friedrich, "Gamification offers a number of components that address a KMS users' need for feedback like points, progress bars, badges, ratings or leaderboards.'[13]. Swacha suggest four categories of points: Socialization (interaction between KMS user), Externalization (did the user create contribution),Combination (give contribution of information), and Internalization (use the contribution) [15]. After that based on Silic and Back (2017) research of the effect of gamification towards knowledge management sharing practice, shows that motivation for knowledge sharing, is strongly linked to performance expectancy, by making achievement visible, knowledge management activities can be rewarded [16]. Therefore, gamification is method for companies to make their employees able to meet the requirement of performance expectancy and strengthen knowledge management [14][16].

\subsection{Gamification for Knowledge Management in Companies}

The theory of implementing gamification into company's knowledge management has happened before, some of the example are: 'How Deloitte made leadership training for senior execs "addictive"; the original problem is because although Deloitte has built leadership training curriculum for senior executive, but the executives are not encourage to start or complete the program, so through gamification they implement gamified elements such as badges, leaderboards, and status symbols to measure participation rate of the executives, the results are average time to complete he training drop by $50 \%$ and the number of users increase by $46.6 \%$ [17].

After that there is also Cisco training to train their employee into a social media master. The problem starts when cisco invested in a 47 courses of global social media training program for their employee to create and leverage the social media skills. To answer the problem, Cisco made the course more engaging by implanting gamification system into the course; the company introduce three basic level of certification with rewards to the training program, the level was divided into Specialist, Strategist, and Masters. Aside from the training program Cisco also mixed in various team challenges from collaboration to competition to get the certification. The results, 650 employees got the required certificate and 12,500 courses taken [18][20]..

It is not new to integrate gamification into knowledge management to improve human resource, for example Deloitte and Cisco has been implementing it and it shows a great result. Therefore according to the problem mentioned in introduction, we made a model for PT. XYZ that could be the answer to help in improving company's knowledge management.

\section{RESEARCH METHOD}

The research method provides an explanation of the stages of research, the time and location of research, and data collection techniques.

\subsection{Research Stages}

In this study several steps will be carried out as a cycle to produce a conclusion. The stages in this study are as follows:

- Problem Identification: At this stage identification will be made of the problems that occur. The problems that have been analyzed are then used as a basis for finding the right solution.

- Literature Review: At this stage will be carried out a study of literature relating to research subjects, namely by studying reference books and similar research results that have previously been carried out by other researchers.

- Data Collection and Processing: At this stage data collection will be carried out using several data collection techniques, namely interviews. The data that has been collected will be processed and analyzed to determine the appropriate model that will be used at a later stage.

- $\quad$ System Design: At this stage a business process design will be made using Activity Diagrams and Use Case Diagrams. While the database design is described in the form of Entity Relationship Diagrams (ERD).

- Discussion: This section will discuss the benefits and obstacles in implementing gamification in Knowledge Management Systems

- Conclusion: The conclusions obtained in this study are based on information, system design, and discussion that was discussed in the previous stage.

\section{A. Time and Location}

At this time researchers and interviewees can't meet directly because of a pandemic that is happening at the study site. So on Monday, April 6th, 2020 researchers conducted interviews with informants by cell phone.

\section{B. Data Collection Techniques}

Data collection in this study uses interviews. Interview is one way to get information by asking directly to the interviewees. In this case, the researcher interviewed one of the Trainers from PT. XYZ to get more in-depth information.

\section{PROPOSED MODEL}

\subsection{Analysis Result}

This analysis produces basic information that is used to design the implementation of gamification on Knowledge Management Systems. The analysis found 7 entities that will be used in this design and then illustrated through Entity Relationship Diagram (ERD). These entities are User, Content, Mission, Mission Details, Discussion, Level, and Badge. After determining the entity, then the business process will be described using the Activity Diagram. All actions in this application will be delivered using Use Case Diagram, there are 2 actors namely Trainer and Promotor and 7 actions namely Login Account, Create Content, Create Mission, Get Content, Create Discussion, Complete Mission, and Create Approval.

\subsection{Entity Relationship Diagram (ERD)}

Entity Relationship Diagram(ERD) is a model for explaining relationships between data in a database based on data base objects that have relationships between relations. ERD to model data structures and relationships between data, to illustrate it uses several notations and symbols. The following Figure 4 is the ERD design plan for this system: 


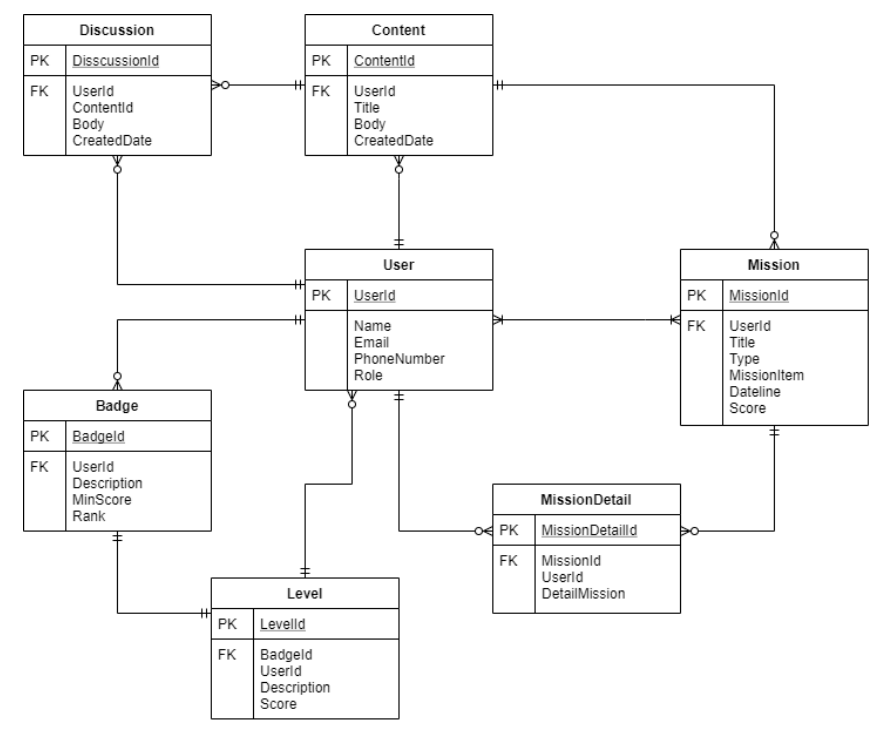

Figure 4 :Entity Relationship Diagram

\subsection{Activity Diagram}

Activity Diagram is the design of the activity flow or work flow in a system that will be run. Activity Diagrams are also used to define or classify the display flow of the system. Activity Diagrams have components with specific shapes that are connected by arrows. The arrows point to the sequence of activities that occur from beginning to end. The following Figure $\mathbf{5}$ is an Activity diagram for this system:

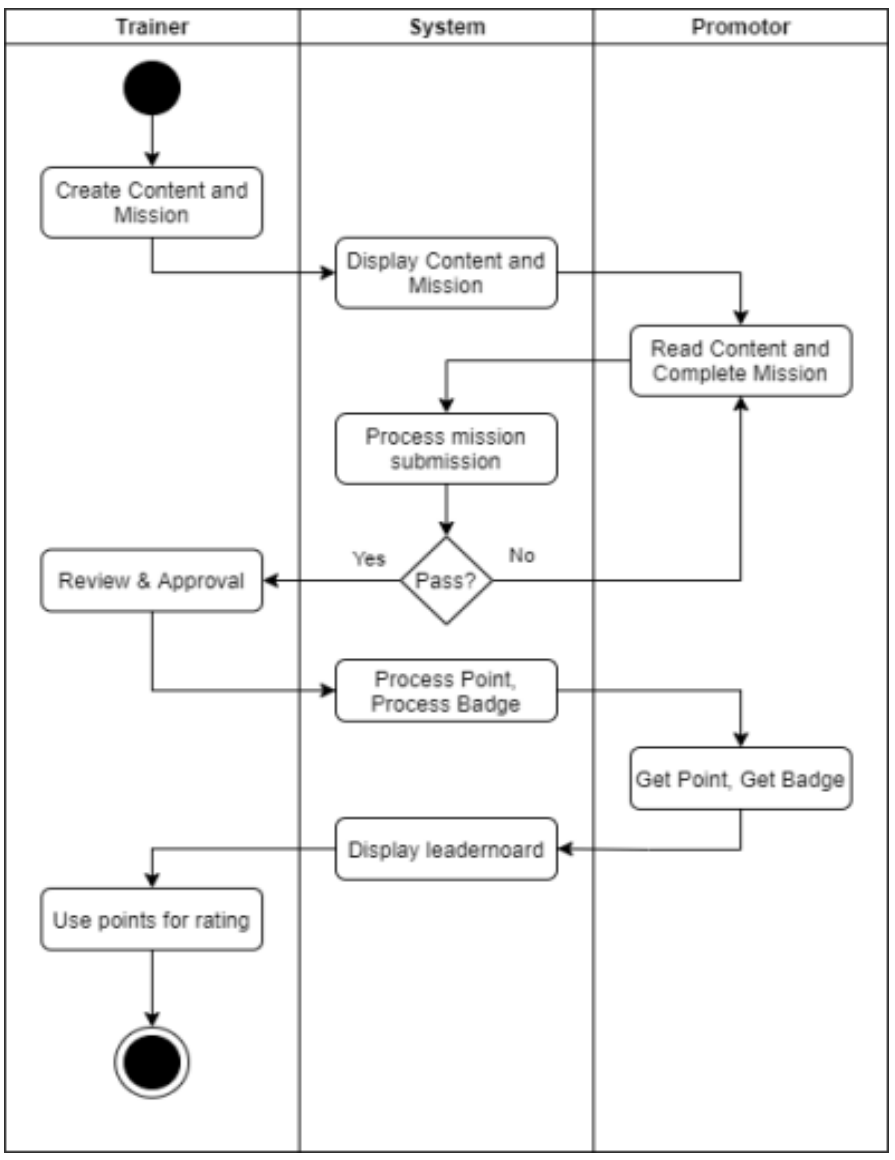

Figure 5 : Activity Diagram
The diagram in the Figure 5 shows the series of activities in this system. The activity starts when the Trainer creates content and missions then sends it to the system intended for the Promotor. After the content and mission have appeared on the system, the Promotor will learn it and then complete the mission at the specified time. The results of the mission carried out by the Promotor will be processed by the system, if it does not meet the requirements of the Promotor will return to work on the mission at the specified time. If it meets the requirements, the system will estimate the points that will be obtained by the user and send the results of the mission that has been done by the Promotor to the Trainer. At this stage the Trainer will conduct a review of the results of the mission then give approval, then the system will process the calculation of points and send them to the Promotor's account. The system will display the leaderboard in real-time after processing the point calculation. This point will be used by the Trainer as one of the Promotor's performance evaluation parameters.

\section{4. [1] Use Case Diagram}

Use Case Diagrams are diagrams that illustrate the interaction between actors and systems. In this case, there are two actors namely Trainer and Promotor with 7 actions as previously explained (See Figure 6).

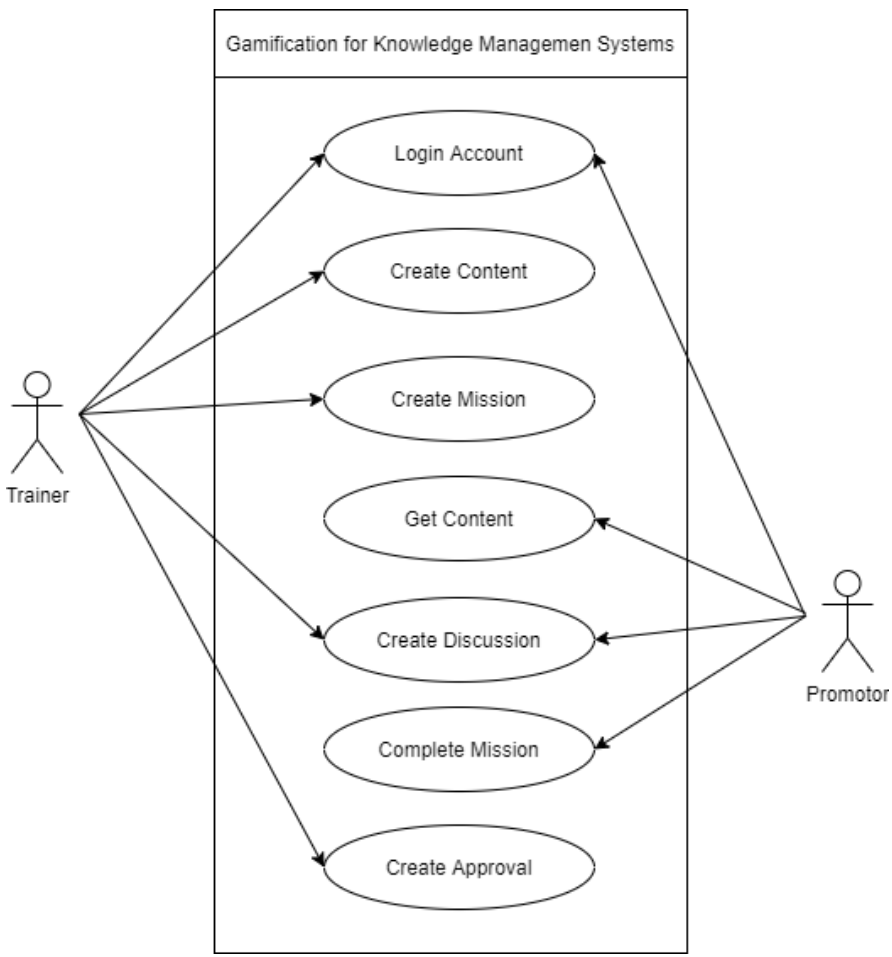

Figure 6 :Use Case Diagram

The Figure 6 shows that the actions performed by the Trainer when interacting with the system are: Login Account, Create Content, Create Mission, Create Discussion, and Create Approval. While the actions carried out by the Promotor are: Account Login, Get Content, Create Discussion, and Complete Mission. 
This system does not need to have a Create Account action because all members of this company already have an account automatically when they join. The following is a brief description of these actions: Create Login is an action that the user needs to access the application. Create Content is an action used by Trainer as a means of sharing knowledge through media such as articles, videos, and images. Create Mission is an action used by trainers to create challenges that aim to measure the level of member knowledge in the form of questions, quizzes, and others. Get Content is an action carried out by the Promotor to obtain learning material that has been provided by the Trainer. Create Discussion is an action used by all actors to discuss learning material. Complete Mission is an action used by the Promotor to complete challenges and get points. Create Approval is the action taken by the Trainer when conducting a review of the results of the challenges worked out by the Promotor and then giving approval.

\section{DISCUSSION}

There have been many scientific articles that discuss the application of gamification on Knowledge Management Systems for students. But it is still very rare for companies to use this gamification for knowledge sharing activities. The application of gamification to the Knowledge Management Systems used by company employees may be new to some, but this technology will be able to increase employee interest in learning that will have a great impact on the quality of the employees which will certainly beneficialto the company.

The application will certainly face challenges. Some of the challenges are from the technology and culture side. Challenges from technology side can be: lack of preparedness among project team, lack of preparedness among the employee, inadequate software training tools, etc. [19]. After that challenges from the culture side can be: low employee morale, failing to communicate, employee lack in technology literacy, etc. [20].

\section{CONCLUSION}

In Conclusion, knowledge management is something that every company need to have, since by investing in their human resource will bring benefit to the company. But sometimes it is hard to make employee engage more especially in the knowledge management system that already exist in their company, that is why gamification is introduced and incorporated into the system, to increase employee's engagement rate. The design of the business process design of this system is made using Activity Diagrams and Use Case Diagrams. While the database design is explained in the form of Entity Relationship Diagrams (ERD). Since as we can see form the data, many not engaged and actively disengaged gamification can be one of the way to solve the problem.

\section{REFERENCES}

[1] Gamee, "5 reasons why playing games is good-GAMEEMedium," 1 January 2017. [Online]. Available: https://medium.com/@gamee/5-reasons-why-playing-gamesis-good-cb119be214f3. [Accessed 18 April 2020].
Teaching Algorithms," 2018. [Online]. Available: https://www.researchgate.net/publication/327892972_The_U se_of_Gamification_for_Teaching_Algorithms. [Accessed 19 April 2020].

[3] J. Long, "5 Factors That Contribute to the Success of Your Business," 7 December 2017. [Online]. Available: https://www.entrepreneur.com/article/305688. [Accessed 19 April 2020].

[4] M. Denton, "The History of Gamification - Journey from 1896 to the 21st Century," 2018. [Online]. Available: https://www.gamify.com/gamification-blog/the-history-ofgamification. [Accessed 19 April 2020].

[5] ACT Consulting, "Pentingkah Employee Engagement Bagi Perusahaan?," 16 August 2018. [Online]. Available: https://actconsulting.co/pentingkah-employee-engagementbagi-perusahaan/. [Accessed 19 April 2020].

[6] P. Pertiwi, "85\% Karyawan Di Dunia Tak Bahagia Dengan Pekerjaannya," 6 March 2018. [Online]. Available: https://www.integrity-indonesia.com/id/blog/2018/03/06/85karyawan-di-dunia-tak-bahagia-dengan-pekerjaannya/. [Accessed 19 April 2020].

[7] V. Lipman, "3 Reasons Employee Engagement Is Declining -- And How Managers Can Improve It," 1 February 2017. [Online]. Available: https://www.forbes.com/sites/victorlipman/2017/02/01/3reasons-employee-engagement-is-declining-and-howmanagers-can-improve-it/\#c8252f52dc17. [Accessed April 2020].

[8] Emerald Campus-Wide Information System, "(PDF) The Effect of Gamification on Motivation and Engagment," November 2017. [Online]. Available: https://www.researchgate.net/publication/321063416_The_E ffect_of_Gamification_on_Motivation_and_Engagement. [Accessed 19 April 2020].

[9] Knowledge Management Tools, "Knowledge Management Definition," 2018. [Online]. Available: https://www.knowledge-management-tools.net/knowledgemanagement-definition.php. [Accessed 19 April 2020].

[10] binus university, "5 ALASAN KENAPA KNOWLEDGE MANAGEMENT DIPERLUKAN," 26 January 2018. [Online]. Available: https://sis.binus.ac.id/2018/01/26/5alasan-kenapa-knowledge-management-diperlukan/. [Accessed 19 April 2020].

[11] S. Garfield, "What is the use of knowledge management?Stan Garfield-Medium," 7 November 2018. [Online]. Available: https://medium.com/@ stangarfield/what-is-theuse-of-knowledge-management-9a3de7c083cd. [Accessed 19 April 2020].

[12] S. Rinc, "Microsoft Word - ML14-667.docx," 25-27 June 2014. [Online]. Available:

https://www.basicknowledge101.com/pdf/Gamification\%20i n\%20Knowledge\%20Management.pdf. [Accessed 19 April 2020].

[13] M. B. F. K. M. W. M. S. J. Friedrich, "Incentive design and gamification for knowledge management," January 2020. [Online]. Available:

https://www.sciencedirect.com/science/article/pii/S01482963 
19300992\#bb0170. [Accessed 19 April 2020].

[14] S. e. al., "The role(s) of gamification in knowledge management," 2016. [Online]. Available: https://strathprints.strath.ac.uk/56368/. [Accessed 19 April 2020].

[15] S. J., "Gamification in knowledge management motivating for knowledge sharing," January 2015. [Online]. Available: https://www.researchgate.net/publication/290455585_Gamifi cation_in_knowledge_management_motivating_for_knowle dge_sharing. [Accessed 19 April 2020].

[16] M. B. A. Silic, "Impact of Gamification on User's Knowledge-Sharing Practices: Relationships between Work Motivation, Performance Expectancy and Work

Engagement," January 2017. [Online]. Available: https://papers.ssrn.com/sol3/papers.cfm?abstract_id=293298 7. [Accessed 19 April 2020].

[17] C. Coy, "5 COMPANIES USING GAMIFICATION TO BOOST BUSINESS RESULTS," 17 April 2015. [Online]. Available: https://www.cornerstoneondemand.com/rework/5companies-using-gamification-boost-business-results. [Accessed 19 April 2020].

[18] raccoongang, "Examples of Gamification in the Workplace," 19 April 2018. [Online]. Available:

https://raccoongang.com/blog/examples-gamificationworkplace/. [Accessed 19 April 2020].

[19] M. Wagner, "7 SOFTWARE IMPLEMENTATION CHALLENGES \& HOW TO SOLVE THEM," 10 October 2019. [Online]. Available: https://blog.walkme.com/7software-implementation-challenges/. [Accessed 19 April 2020].

[20] Shane,M., Wisnudrajat,L.,Wang,G.,Kaburuan,E.R. 2020. International Journal of Advanced Trends in Computer Science and Engineering, 9(3),pp.2667-2672. 